\title{
Base-Promoted C-O Bond Cleavage of Primary Alcohols by Iridium(III) Porphyrin Chloride
}

\author{
Yongjun Bian, ${ }^{\dagger, \ddagger}$ Xingyu $\mathrm{Qu}^{\dagger, \ddagger}$ and Kin Shing Chan ${ }^{*,, \S}$ \\ ${ }^{\dagger}$ College of Chemistry and Chemical Engineering, Jinzhong University, Yuci 030619, P. R. of \\ China \\ ${ }^{\ddagger}$ Department of Chemistry, The Chinese University of Hong Kong, Shatin, New Territories, Hong \\ Kong, P. R. of China \\ ${ }^{8}$ School of Chemistry and Chemical Engineering, Nanjing University, Nanjing 210093, P. R. of \\ China \\ Email: ksc@cuhk.edu.hk
}

\section{Supporting Information}

\section{List of Contents}

$\begin{array}{ll}\text { 1. The scope of substituted benzyl alcohols } & \text { S2 }\end{array}$

$\begin{array}{ll}\text { 2. The scope of alkyl alcohols } & \text { S2 }\end{array}$

3. Relative reactivity of substituted benzyl alcohols $\quad$ S3

4. ${ }^{1} \mathrm{H}$ NMR Spectra S5

$\begin{array}{ll}\text { 5. References } & \text { S15 }\end{array}$ 
1. Table S1. The scope of substituted benzyl alcohols

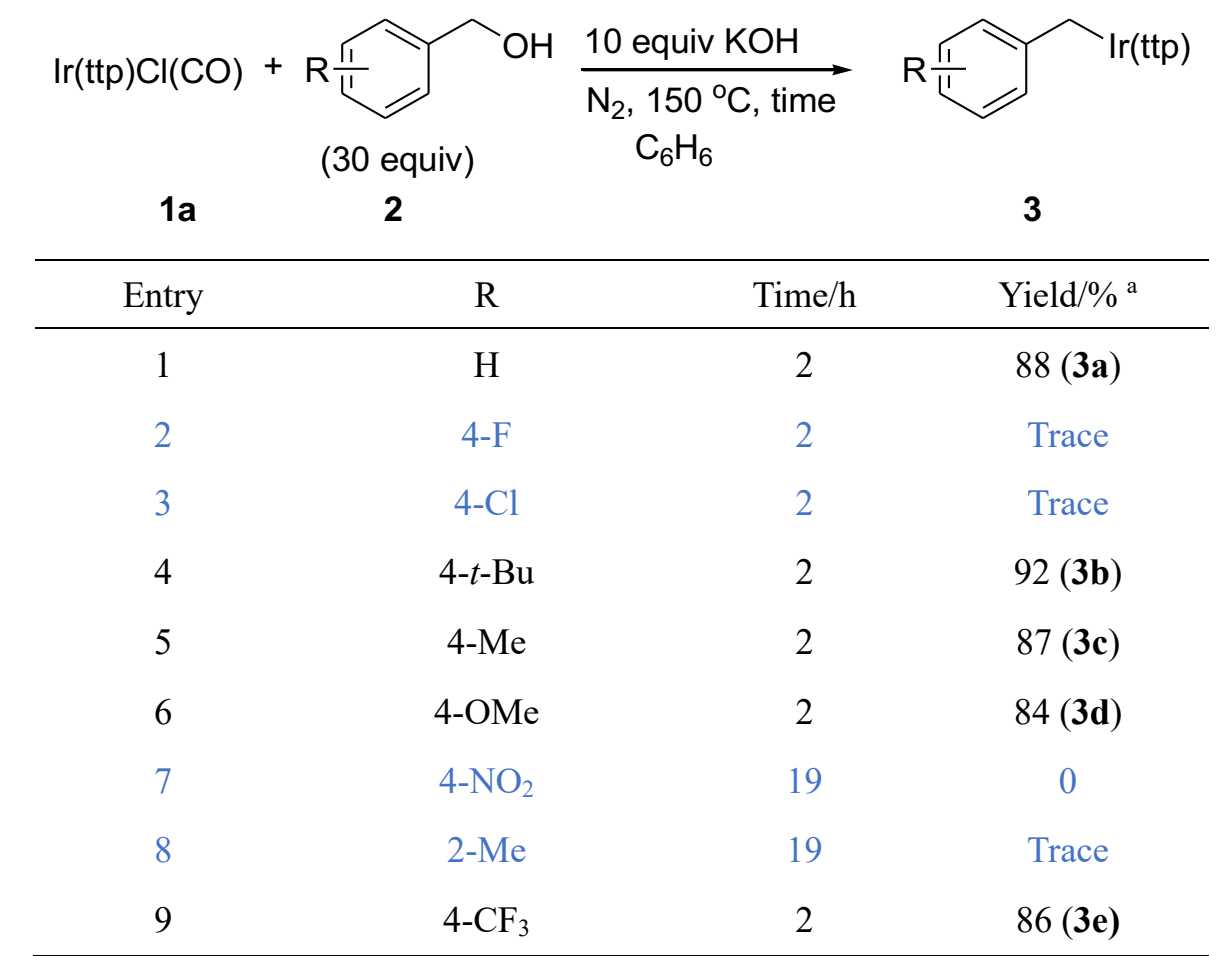

${ }^{a}$ isolated yield

2. Table S2. The scope of alkyl alcohols

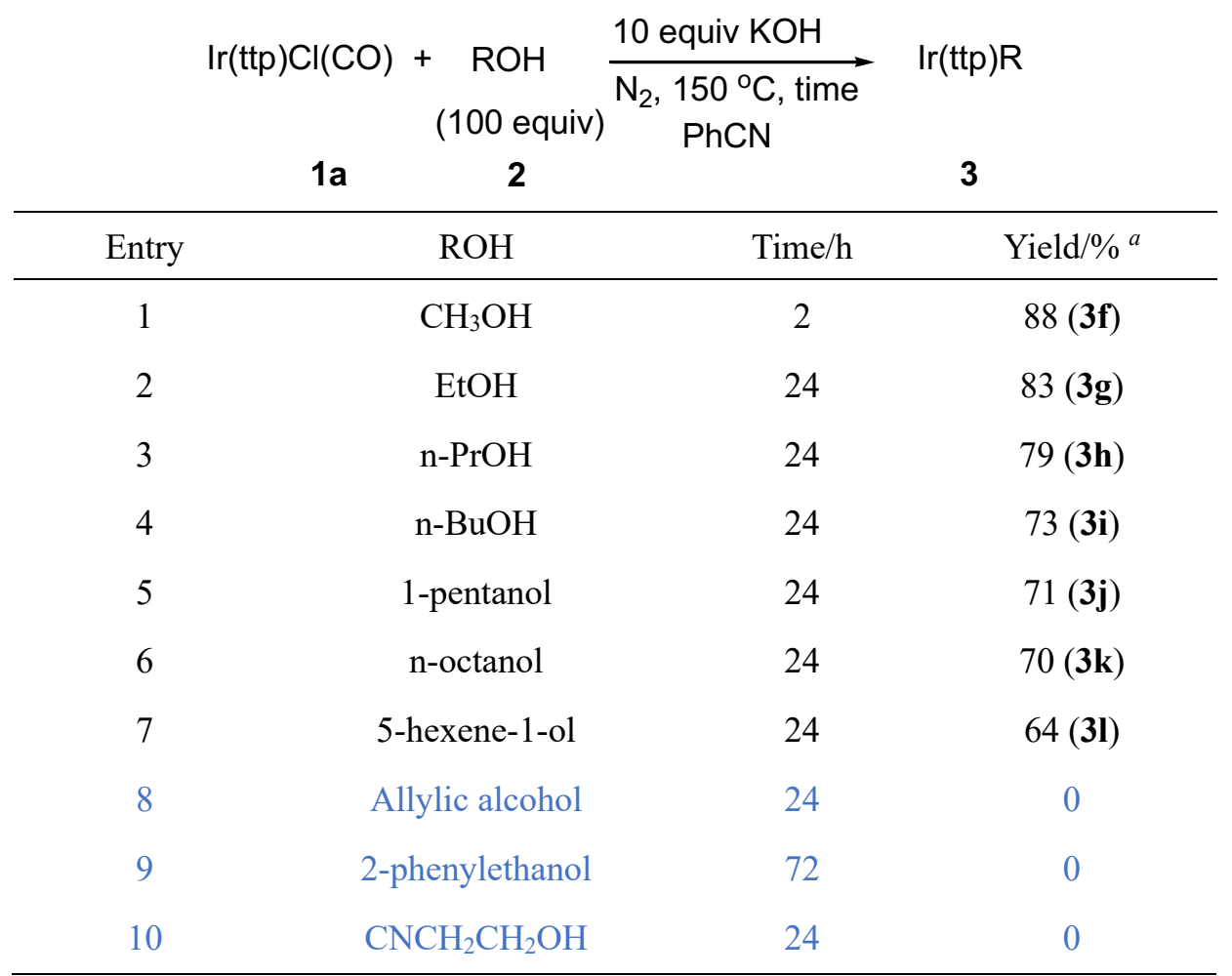

${ }^{a}$ isolated yield. 
3. Relative reactivity of substituted benzyl alcohols

\begin{tabular}{ccccc}
$\mathrm{R}^{1}$ & $\mathrm{R}^{2}$ & Yield ratio of products ${ }^{a}$ & ${\text { Total yield } / \%{ }^{b}}_{(30 \text { equiv })}$ \\
\hline Entry & $\mathrm{H}$ & $\mathrm{CH}_{3}$ & $\mathbf{3 a} / \mathbf{3 c}=1: 1.7$ & 95 \\
\hline 1 & $\mathrm{H}$ & $\mathrm{OCH}_{3}$ & $\mathbf{3 a} / \mathbf{3 d}=1: 2.7$ & 78 \\
3 & $\mathrm{H}$ & $\mathrm{CF}_{3}$ & $\mathbf{3 a} / \mathbf{3 e}=1.2: 1$ & 96 \\
4 & $\mathrm{OCH}_{3}$ & $\mathrm{CF}_{3}$ & $\mathbf{3 d} / \mathbf{3 e}=3.0: 1$ & 79 \\
\hline
\end{tabular}

${ }^{a}$ Ratio of $\mathrm{Rh}(\mathrm{ttp}) \mathrm{C}_{6} \mathrm{H}_{4}\left(p\right.$-FG) and $\mathrm{Rh}(\mathrm{ttp}) \mathrm{Bn}$ in the crude product obtained by ${ }^{1} \mathrm{H}$ NMR spectroscopy.

${ }^{b}$ NMR yield.

Reaction of $\operatorname{Ir}(\mathrm{ttp})(\mathrm{CO}) \mathrm{Cl}$ with benzyl alcohol and 4-methylbenzyl alcohol: $\operatorname{Ir}(\operatorname{ttp}) \mathrm{Cl}(\mathrm{CO})$ (1a; $11.6 \mathrm{mg}, 0.0125 \mathrm{mmol}), \mathrm{KOH}$ (7.0 mg, $0.125 \mathrm{mmol})$, benzyl alcohol (2a; $41.0 \mathrm{mg}, 0.375 \mathrm{mmol}$ ) and 4-methylbenzyl alcohol (2c; $45.8 \mathrm{mg}, 0.375 \mathrm{mmol}$ ) was added into benzene $(1.5 \mathrm{~mL})$ in a Teflon screw-capped tube and degassed for three freeze-pump-thaw cycles, refilled with $\mathrm{N}_{2}$, and heated at $150{ }^{\circ} \mathrm{C}$ for $2 \mathrm{~h}$. The excess alcohol and benzene were removed by vacuum distillation. The total yield of $\operatorname{Ir}(\operatorname{ttp}) \mathrm{Bn}$ (3a) and $\operatorname{Ir}(\operatorname{ttp})(4-\mathrm{Me}) \mathrm{Bn}(3 \mathrm{c})$ was determined to be $95 \%$ using 1,2-dichloroethane as the internal standard. The product ratio of $3 \mathbf{a}: 3 \mathbf{c}$ was calculated to be 1:1.7 from ${ }^{1} \mathrm{H}$ NMR spectroscopy.

Reaction of $\operatorname{Ir}(\operatorname{ttp})(\mathrm{CO}) \mathrm{Cl}$ with benzyl alcohol and 4-methoxylbenzyl alcohol: $\operatorname{Ir}(\operatorname{ttp}) \mathrm{Cl}(\mathrm{CO})$ (1a; $11.6 \mathrm{mg}, 0.0125 \mathrm{mmol}), \mathrm{KOH}$ (7.0 mg, $0.125 \mathrm{mmol})$, benzyl alcohol (2a; $41.0 \mathrm{mg}, 0.375 \mathrm{mmol})$ and 4-methoxylbenzyl alcohol $(2 \mathrm{~d} ; 51.8 \mathrm{mg}, 0.375 \mathrm{mmol})$ was added into benzene $(1.5 \mathrm{~mL})$ in a Teflon screw-capped tube and degassed for three freeze-pump-thaw cycles, refilled with $\mathrm{N}_{2}$, and heated at $150{ }^{\circ} \mathrm{C}$ for $2 \mathrm{~h}$. The excess alcohol and benzene were removed by vacuum distillation. The total yield of $\operatorname{Ir}(\mathrm{ttp}) \mathrm{Bn}$ (3a) and $\operatorname{Ir}(\operatorname{ttp})(4-\mathrm{OMe}) \mathrm{Bn}$ (3d) was determined to be $78 \%$ using 1,2-dichloroethane as the internal standard. The product ratio of $\mathbf{3 a}: 3 \mathbf{d}$ was calculated to be 1:2.7 from ${ }^{1} \mathrm{H}$ NMR spectroscopy

Reaction of $\operatorname{Ir}(\mathrm{ttp})(\mathrm{CO}) \mathrm{Cl}$ with benzyl alcohol and 4-trifluoromethylbenzyl alcohol: $\operatorname{Ir}(\operatorname{ttp}) \mathrm{Cl}(\mathrm{CO})(\mathbf{1 a} ; 11.6 \mathrm{mg}, 0.0125 \mathrm{mmol}), \mathrm{KOH}(7.0 \mathrm{mg}, 0.125 \mathrm{mmol})$, benzyl alcohol (2a; $41.0 \mathrm{mg}, 0.375 \mathrm{mmol})$ and 4-trifluoromethylbenzyl alcohol (2e; $66.1 \mathrm{mg}, 0.375 \mathrm{mmol})$ was added into benzene $(1.5 \mathrm{~mL})$ in a Teflon screw-capped tube and degassed for three freeze-pump-thaw cycles, refilled with $\mathrm{N}_{2}$, and heated at $150{ }^{\circ} \mathrm{C}$ for $2 \mathrm{~h}$. The excess alcohol and benzene were removed by vacuum distillation. The total yield of $\operatorname{Ir}(\operatorname{ttp}) \mathrm{Bn}$ (3a) and $\operatorname{Ir}(\mathrm{ttp})\left(4-\mathrm{CF}_{3}\right) \mathrm{Bn}$ (3e) was determined to be $96 \%$ using 1,2-dichloroethane as the internal standard. The product ratio of $3 \mathbf{a}: 3 \mathbf{e}$ was calculated to be 1.2:1 from ${ }^{1} \mathrm{H}$ NMR 
spectroscopy.

Reaction of $\operatorname{Ir}(\operatorname{ttp})(\mathrm{CO}) \mathrm{Cl}$ with 4-methoxylbenzyl alcohol and 4-trifluoromethylbenzyl alcohol: $\operatorname{Ir}(\operatorname{ttp}) \mathrm{Cl}(\mathrm{CO}) \quad(\mathbf{1 a} ; 11.6 \mathrm{mg}, 0.0125 \mathrm{mmol}), \mathrm{KOH}(7.0 \mathrm{mg}, 0.125 \mathrm{mmol})$, 4-methoxylbenzyl alcohol (2d; $51.8 \mathrm{mg}, 0.375 \mathrm{mmol})$ and 4-trifluoromethylbenzyl alcohol (2e; $66.1 \mathrm{mg}, 0.375 \mathrm{mmol}$ ) was added into benzene $(1.5 \mathrm{~mL})$ in a Teflon screw-capped tube and degassed for three freeze-pump-thaw cycles, refilled with $\mathrm{N}_{2}$, and heated at $150{ }^{\circ} \mathrm{C}$ for $2 \mathrm{~h}$. The excess alcohol and benzene were removed by vacuum distillation. The total yield of $\operatorname{Ir}(\operatorname{ttp})(4-\mathrm{OMe}) \mathrm{Bn}(\mathbf{3 d})$ and $\operatorname{Ir}(\operatorname{ttp})\left(4-\mathrm{CF}_{3}\right) \mathrm{Bn}(\mathbf{3 e})$ was determined to be $79 \%$ using 1,2-dichloroethane as the internal standard. The product ratio of $3 \mathbf{d}: 3 \mathbf{e}$ was calculated to be 3:1 from ${ }^{1} \mathrm{H}$ NMR spectroscopy. 


\section{4. ${ }^{1}$ H NMR Spectra}

Figure S1. ${ }^{1} \mathrm{H}$ NMR Spectrum of $\operatorname{Ir}(\mathrm{ttp}) \mathrm{Bn}(\mathbf{3 a})\left(\mathrm{CDCl}_{3}\right)^{1}$

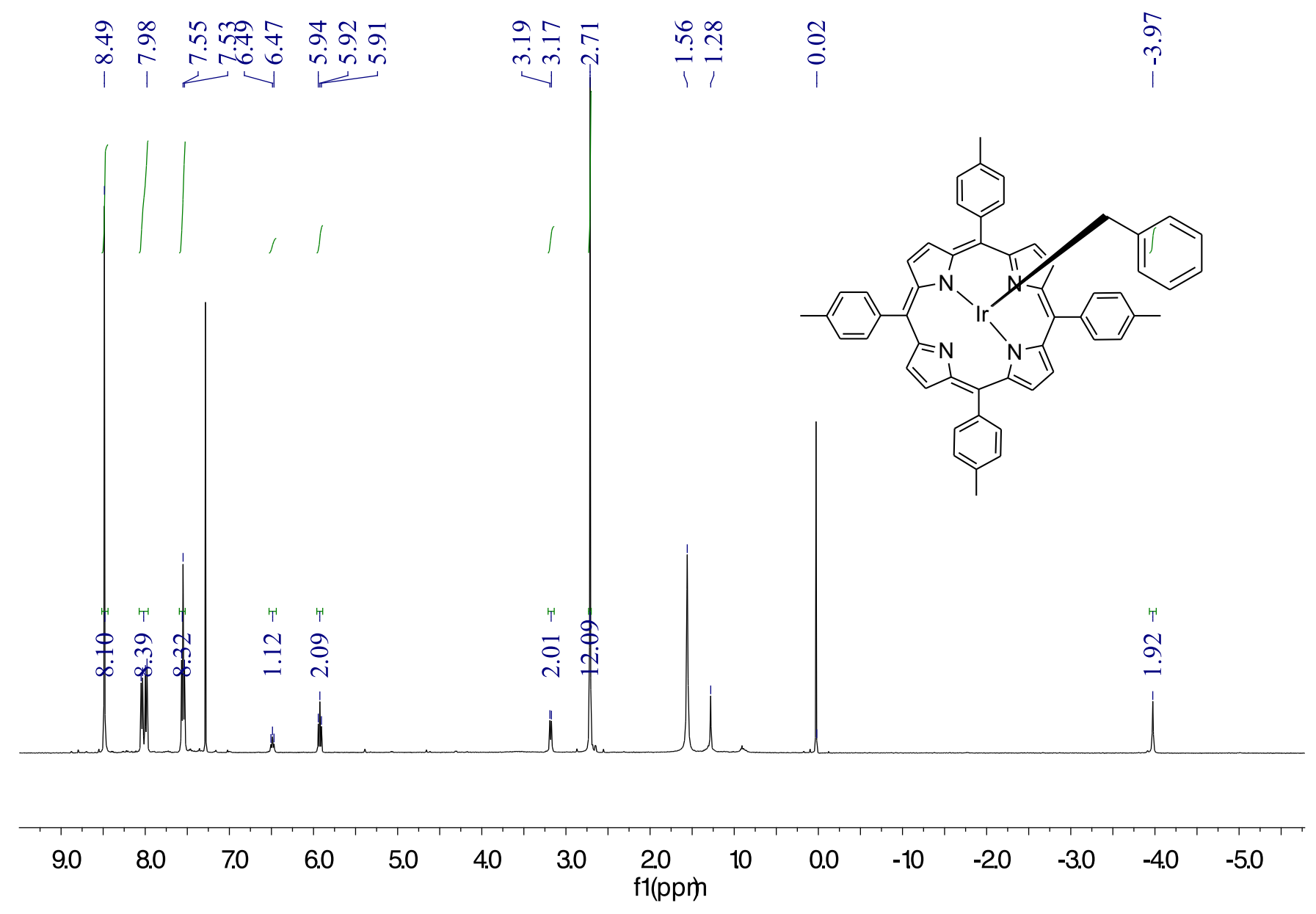


Figure S2. ${ }^{1} \mathrm{H}$ NMR Spectrum of $\operatorname{Ir}(\operatorname{ttp})(4-t-\mathrm{Bu}) \mathrm{Bn}(\mathbf{3 b})\left(\mathrm{CDCl}_{3}\right)^{1}$

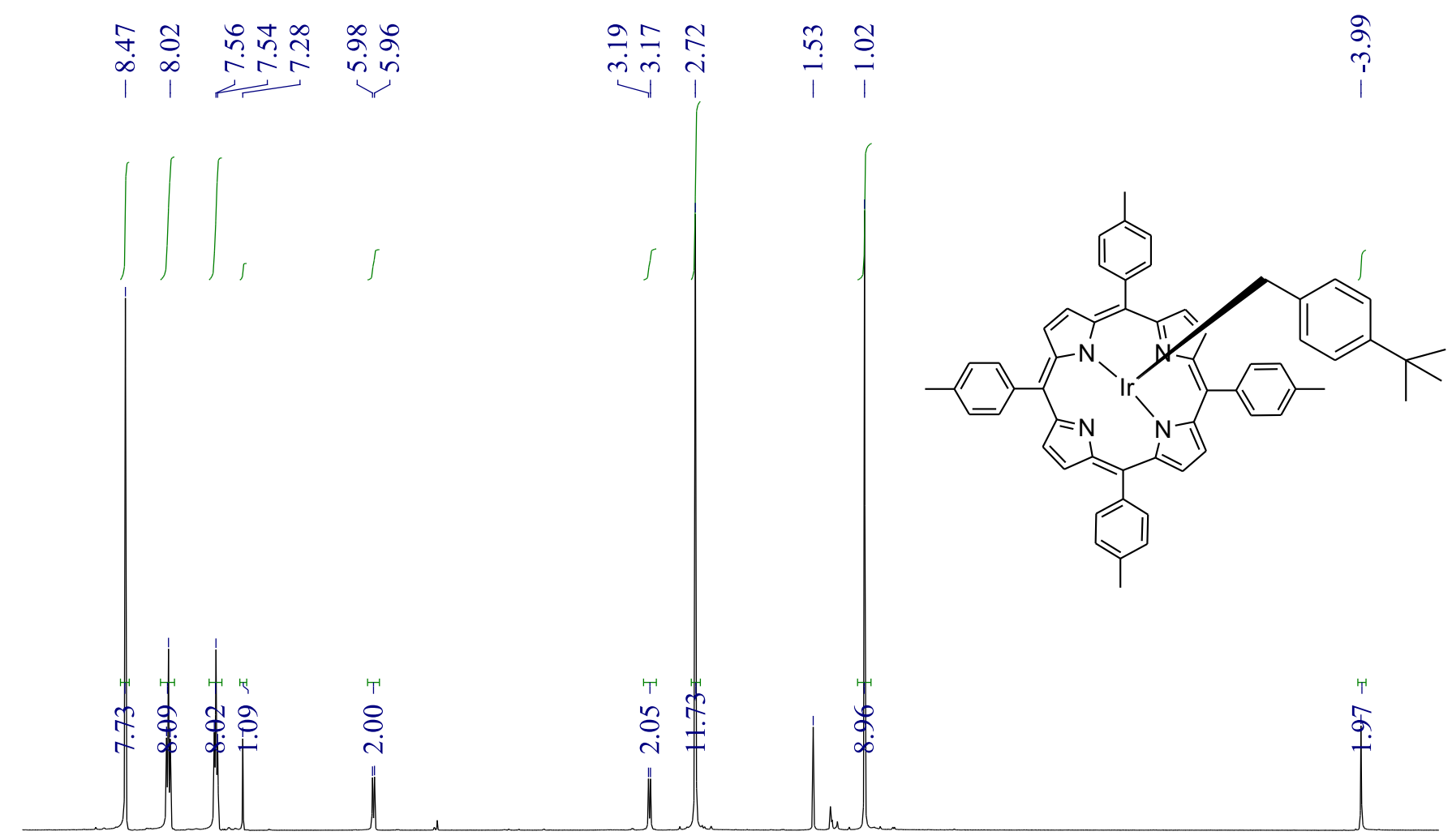

$\begin{array}{llllllllllllllllll} & 9.5 & 8.5 & 7.5 & 6.5 & 5.5 & 4.5 & 3.5 & \underset{\mathrm{f} 1(\mathrm{ppm}}{2.5} & 15 & 10 & 0.0 & -10 & -2.0 & -3.0 & -4.0\end{array}$


Figure S3. ${ }^{1} \mathrm{H}$ NMR Spectrum of $\operatorname{Ir}(\mathrm{ttp})(4-\mathrm{OMe}) \mathrm{Bn}(\mathbf{3 d})\left(\mathrm{CDCl}_{3}\right)^{2}$

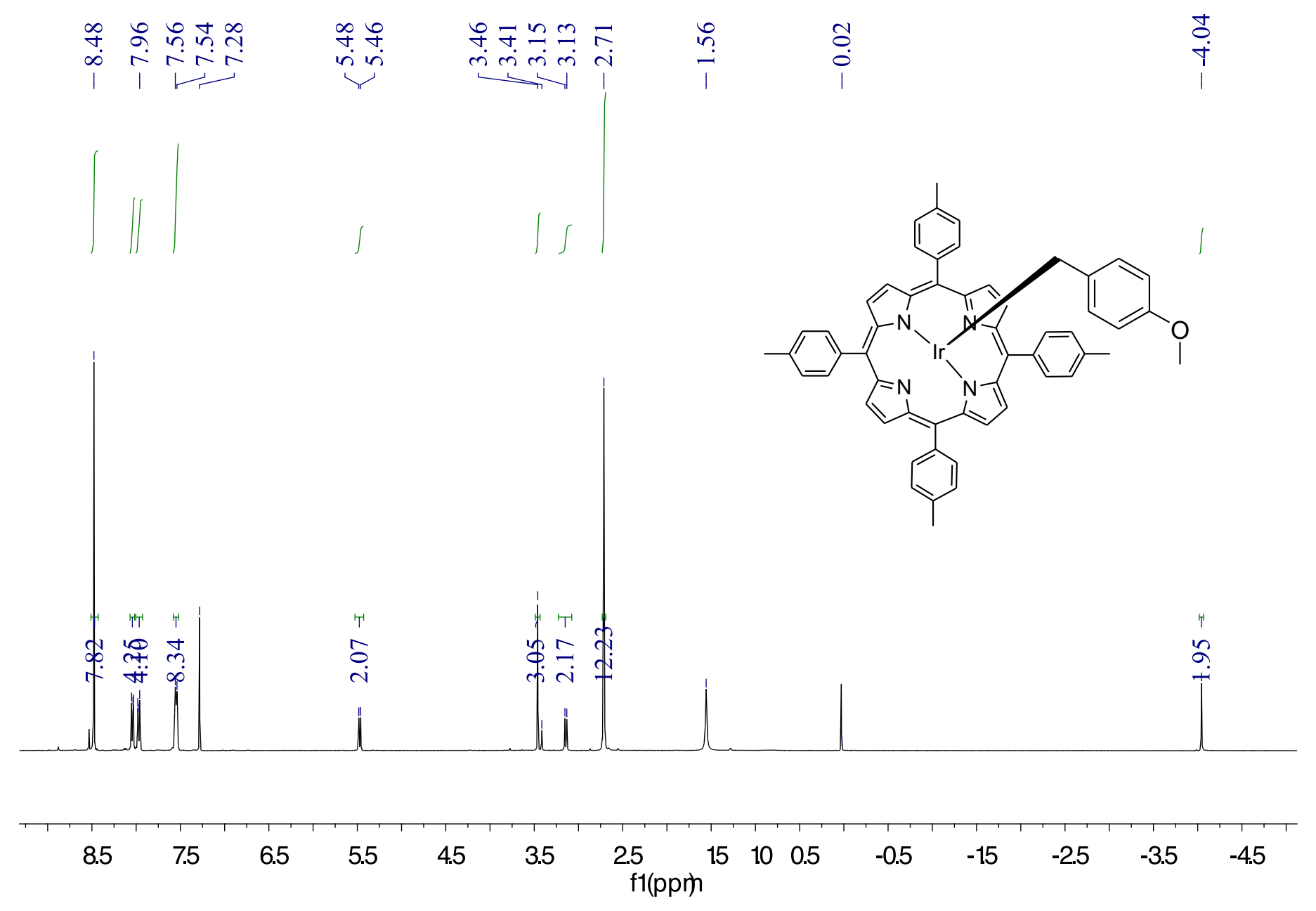


Figure S4. ${ }^{1} \mathrm{H}$ NMR Spectrum of $\operatorname{Ir}(\operatorname{ttp})\left(4-\mathrm{CF}_{3}\right) \mathrm{Bn}(3 \mathbf{e})\left(\mathrm{CDCl}_{3}\right)^{2}$

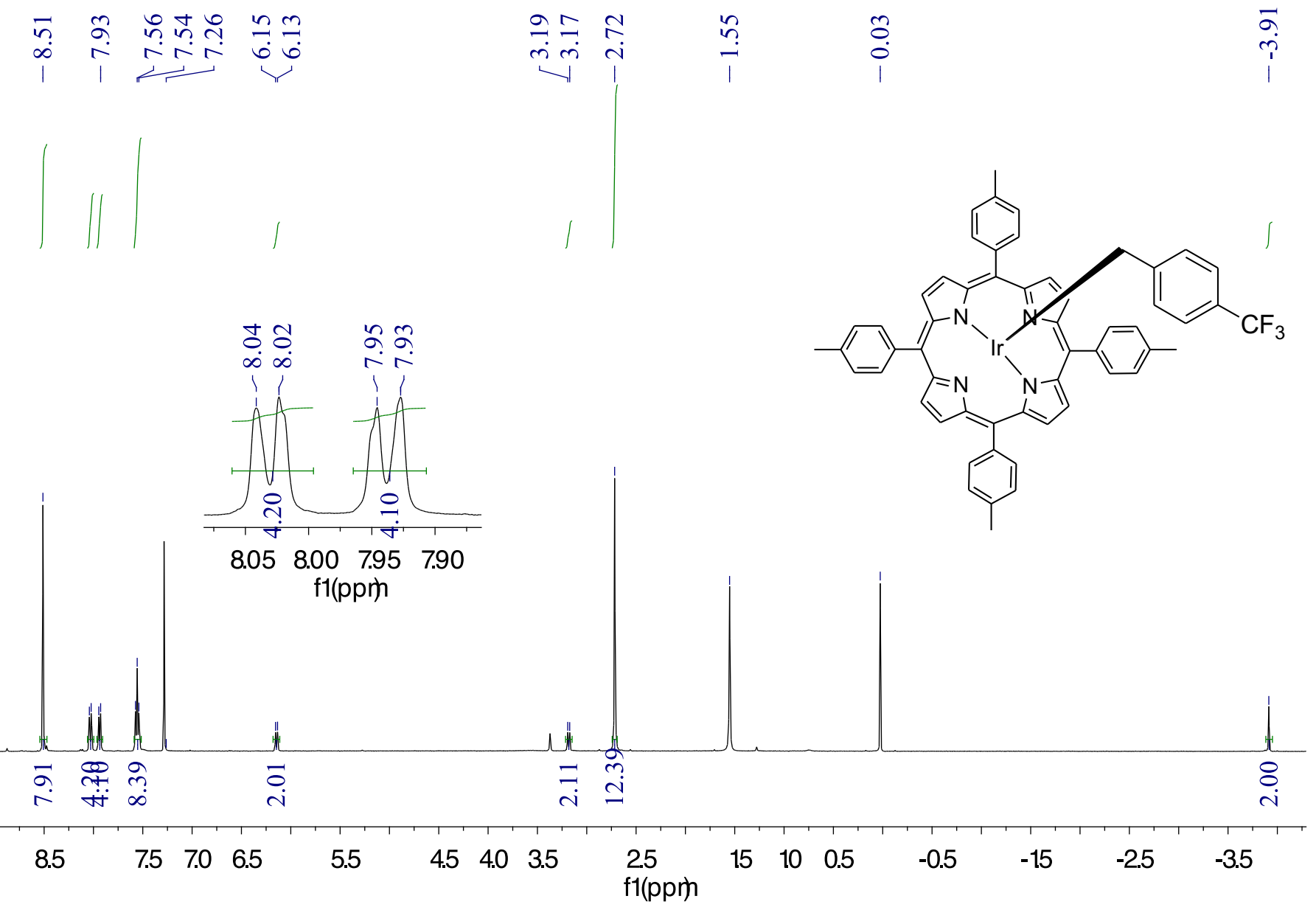


Figure S5. ${ }^{1} \mathrm{H}$ NMR Spectrum of $\operatorname{Ir}(\operatorname{ttp}) \mathrm{Me}(\mathbf{3 f})\left(\mathrm{CDCl}_{3}\right)^{6}$

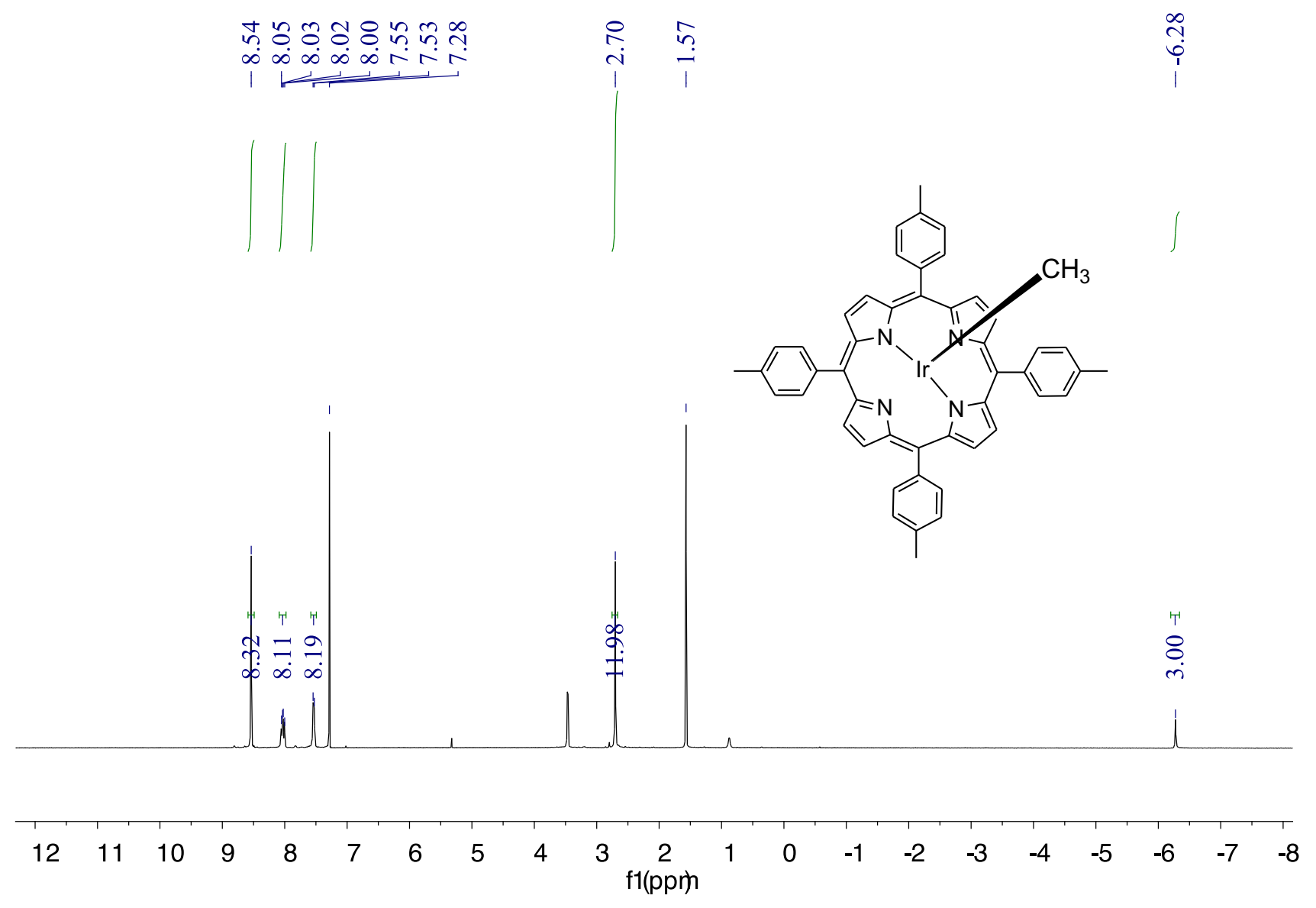


Figure S6. ${ }^{1} \mathrm{H}$ NMR Spectrum of $\operatorname{Ir}(\operatorname{ttp}) \operatorname{Et}(\mathbf{3 g})\left(\mathrm{CDCl}_{3}\right)^{4}$

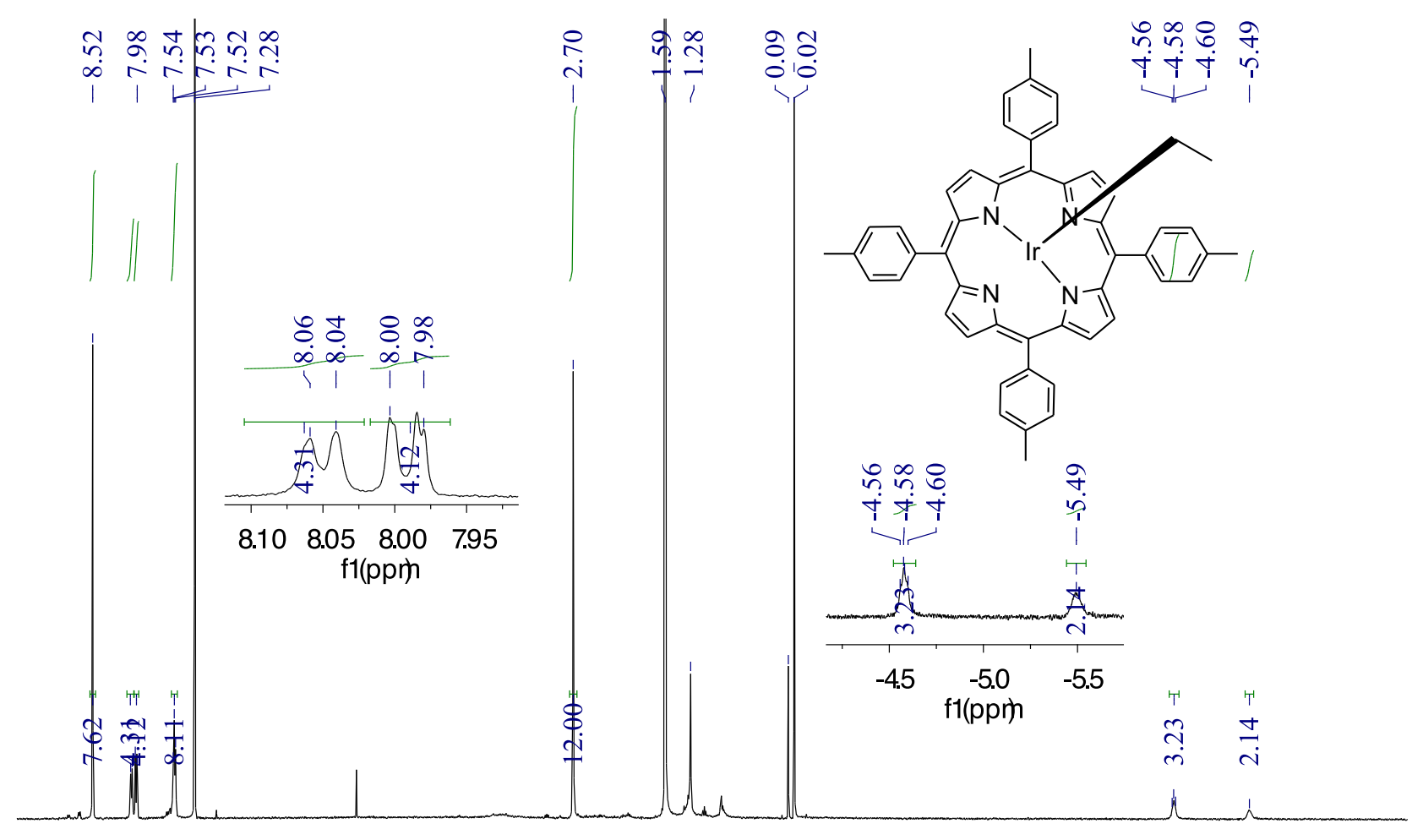

\begin{tabular}{|c|c|c|c|c|c|c|c|c|c|c|c|c|c|c|c|c|}
\hline 9 & 8 & 7 & 6 & 5 & 4 & 3 & 2 & $\begin{array}{c}1 \\
\mathrm{f} 1(\mathrm{pp})\end{array}$ & 0 & -1 & -2 & -3 & -4 & -5 & -6 & -7 \\
\hline
\end{tabular}


Figure S7. ${ }^{1} \mathrm{H}$ NMR Spectrum of $\operatorname{Ir}(\operatorname{ttp})(n-\operatorname{Pr})(3 \mathbf{h})\left(\mathrm{CDCl}_{3}\right){ }^{4}$

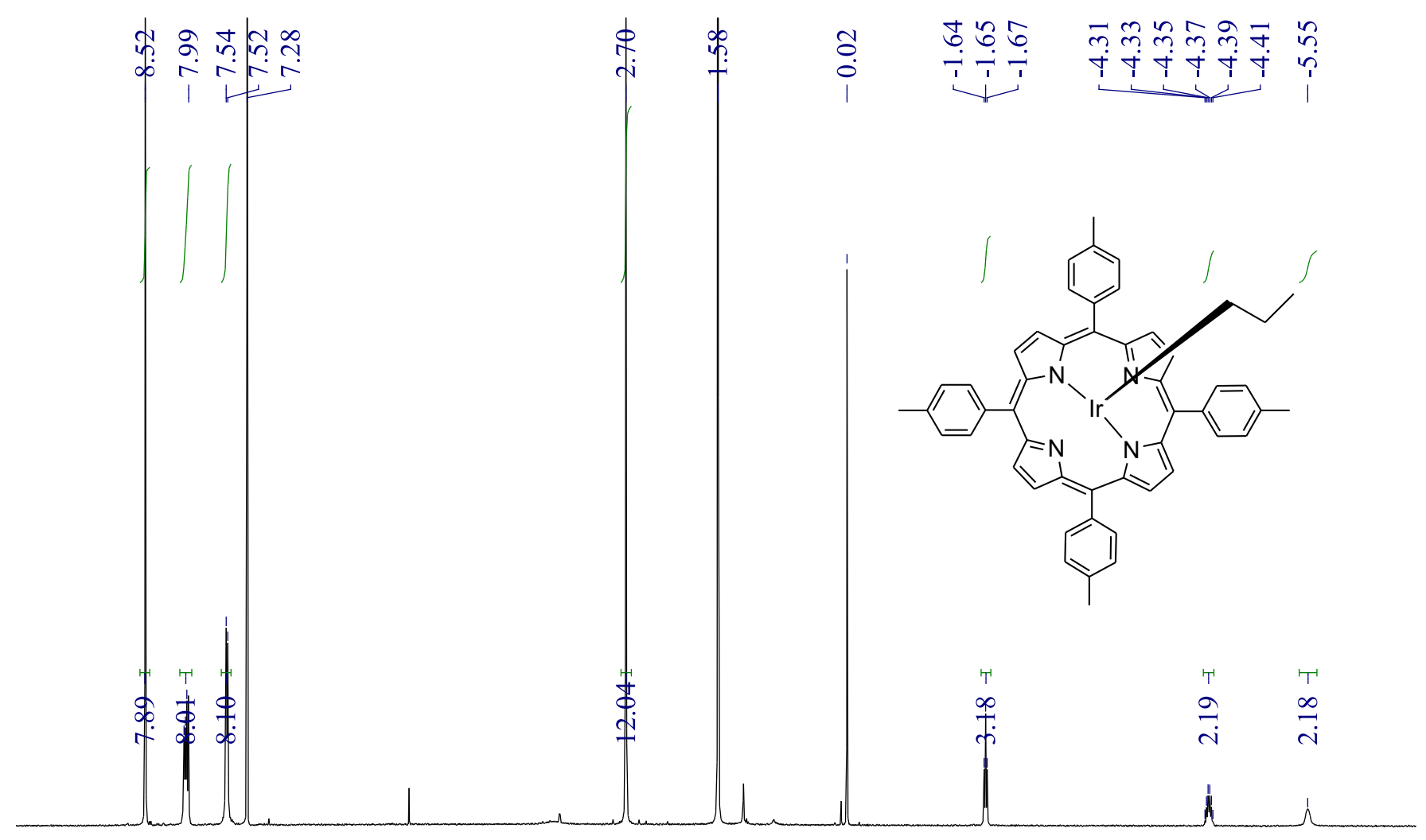

\begin{tabular}{|c|c|c|c|c|c|c|c|c|c|c|c|c|c|c|c|}
\hline 10 & 9 & 8 & 7 & 6 & 5 & 4 & 3 & $\begin{array}{l}2 \\
\mathrm{f} 1(\mathrm{pp}\end{array}$ & 1 & 0 & -1 & -2 & -3 & -4 & -5 \\
\hline
\end{tabular}


Figure S8. ${ }^{1} \mathrm{H}$ NMR Spectrum of $\operatorname{Ir}(\operatorname{ttp})(n$-pentyl $)(\mathbf{3 j})\left(\mathrm{CDCl}_{3}\right)^{3}$
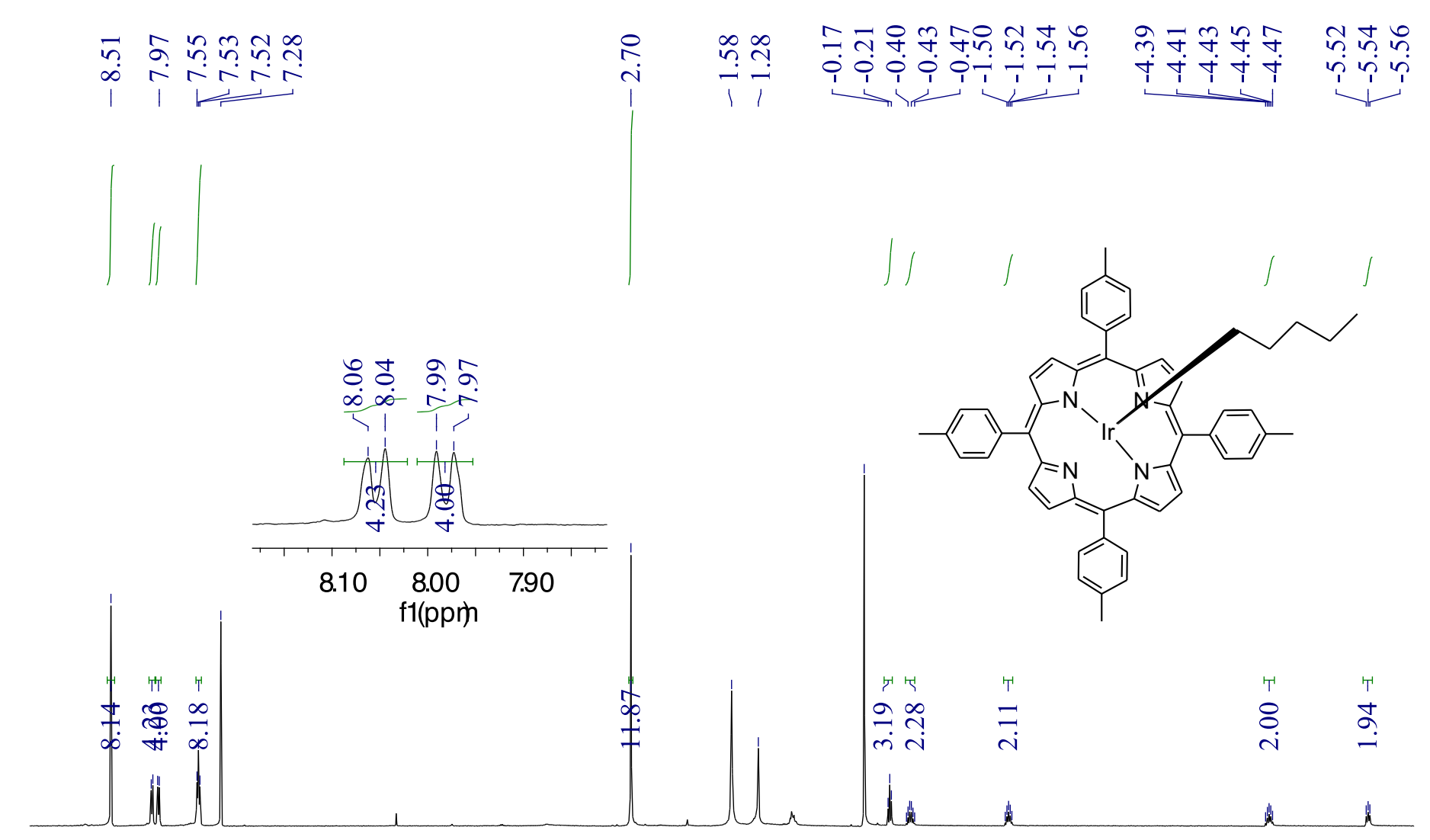

\begin{tabular}{|c|c|c|c|c|c|c|c|c|c|c|c|c|c|c|}
\hline 9 & 8 & 7 & 6 & 5 & 4 & 3 & $\begin{array}{l}2 \\
f 1(p p r)\end{array}$ & 1 & 0 & -1 & -2 & -3 & -4 & -5 \\
\hline
\end{tabular}


Figure S9. ${ }^{1} \mathrm{H}$ NMR Spectrum of $\operatorname{Ir}(\mathrm{ttp})(n$-octyl $)(\mathbf{3 k})\left(\mathrm{CDCl}_{3}\right)^{3}$
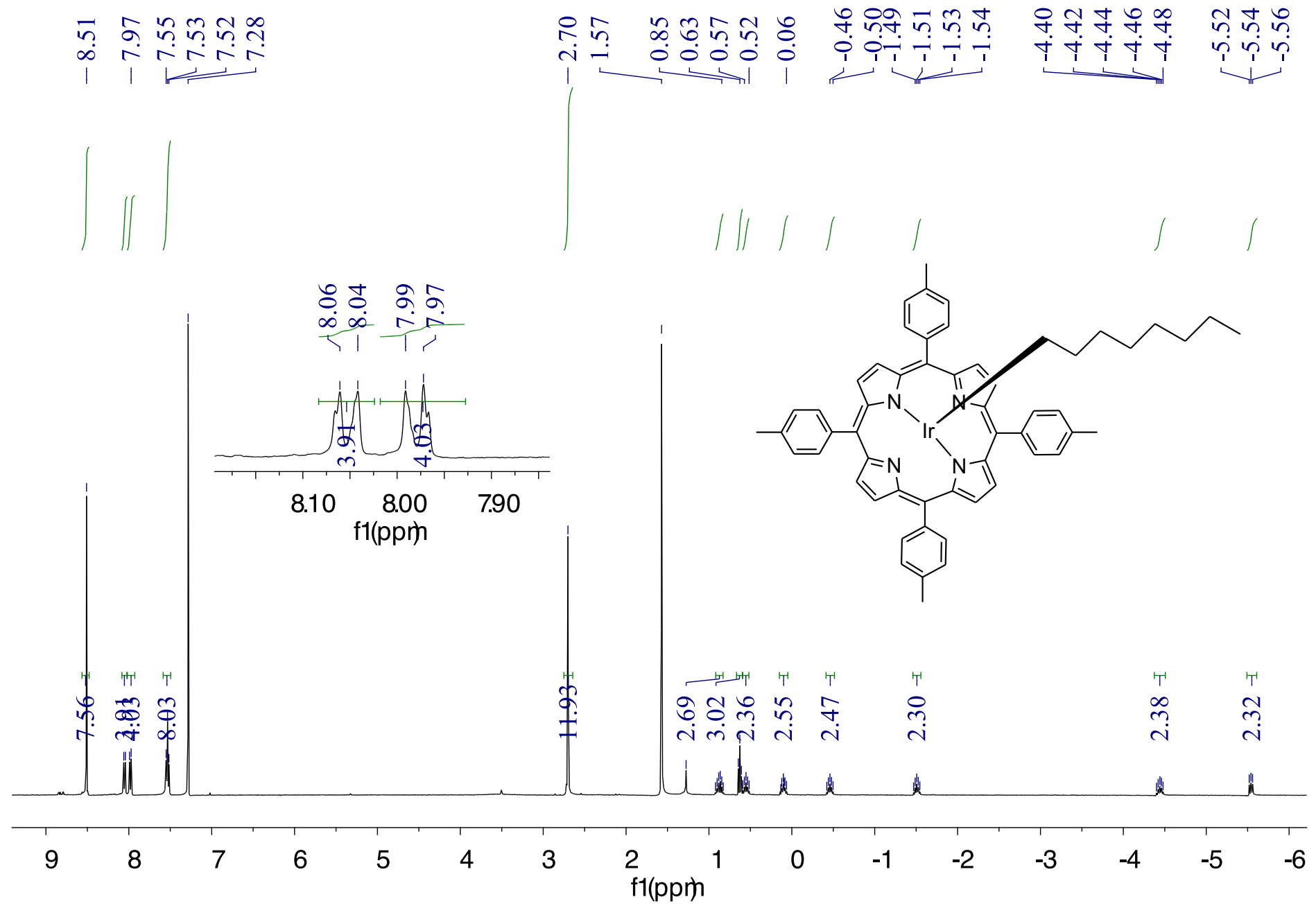
Figure S10. ${ }^{1} \mathrm{H}$ NMR Spectrum of $\operatorname{Ir}(\mathrm{ttp})\left(5\right.$-hexenyl) $(3 \mathrm{l})\left(\mathrm{CDCl}_{3}\right)^{3}$

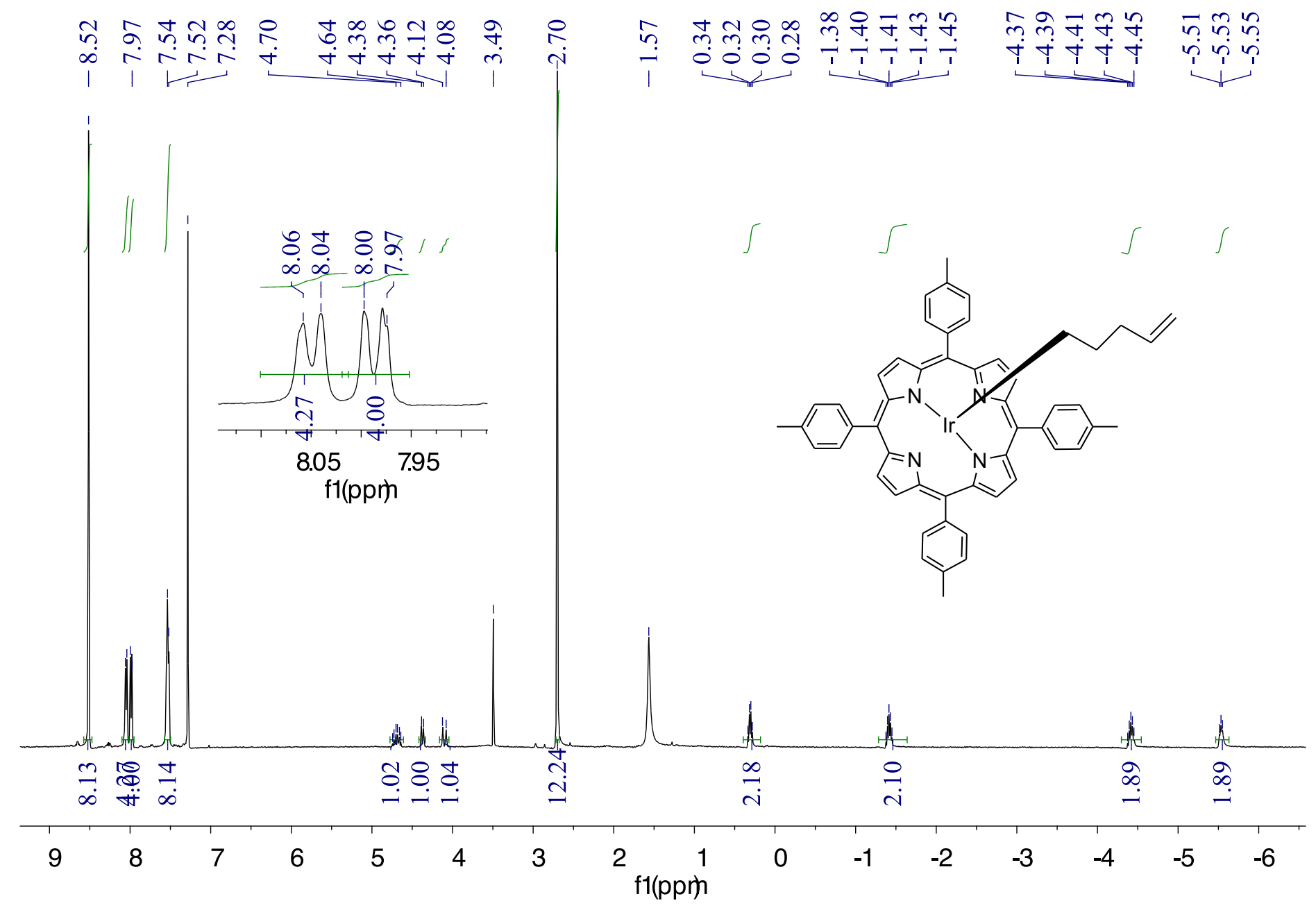




\section{References}

[1] Cheung, C. W.; Chan, K. S. Base-Promoted Selective Activation of Benzylic Carbon-Hydrogen Bonds of Toluenes by Iridium (III) Porphyrin. Organometallics. 2008, 27, 3043-3055.

[2] Chen, C.; Chan, K. S. Alkyl Carbon-Oxygen Bond Cleavage of Aryl Alkyl Ethers by Iridium-Porphyrin and Rhodium-Porphyrin Complexes in Alkaline Media. Organometallics. 2017, 36, 3456-3464.

[3] Zuo, H.; Liu, Z.; Yang, W.; Zhou, Z.; Chan, K. User-friendly aerobic reductive alkylation of iridium (III) porphyrin chloride with potassium hydroxide: scope and mechanism. Dalton Trans., 2015, 44, 20618-20625.

[4] Yeung, S. K.; Chan, K. S. Selective Oxidation of (Porphyrinato) iridium (III) Arylethyls by Nitroxide: Evidence for Stabilization of Carbon-Centered $\mathrm{Ir}-\mathrm{CH}_{2}-\mathrm{CHR} \cdot$ Radicals by Iridium. Organometallics. 2005, 24, 6426-6430. 